Cherenkov Mykhailo,

Doctor of Philosophy, professor of Ukrainian Catholic University

\title{
CHALLENGING RELIGIOUS FREEDOM AND RELIGIOUS PLURALITY OF UKRAINE: THE IDEOLOGY AND TERROR OF "RUSSIAN WORLD"
}

The articale is devoted to analysis of religious motives behind of separatism at Eastern Ukraine. As authors theses have shown, Orthodox fundamentalism is no less aggressive than "Islamic fundamentalism", and the "Russian spring" is no less bloody than its "Arab" counterpart. Because this species of Orthodoxy has government support and aspires to a role in politics, it can be called "political Orthodoxy." Morever, recently "political Orthodoxy" has manifested itself in the form of "Orthodox terrorism" on Ukrainian territory occupied by pro-Russian separatists. There is no doubt that the persecution of individuals and groups based on religion that we are witnessing is part of a coherent policy aimed at creating a "Russian world".

Keywords: religion; East Ukraine; separatism; Orthodoxy; "Russian world".

\section{REFERENCES}

1. Putin said that Crimea has a sacred significance for Russia, available at: http://ria.ru/politics/20141204/1036533683.html (rus).

2. Declaration of Russian identity, available at: http://www.patriarchia.ru/db/text/508347.html (rus).

3. Orthodox people would never fight vs. Noworussia. Interview of Igor Druz, available at: http://narodsobor.com.ua/news/view/ 139/ (rus).

4. Druz I. Where the threat to Orthodoxy in Ukraine?, available at: http://rusvesna.su/news/1403468914 (rus).

5. Resolution XXXIV of Congress Union of Evangelical Christians-Baptists of Russia on the situation in the fraternal Ukraine, available at: http://baptist.org.ru/news/main/view/rezolutsiya-34-sezda-po-ukraine (rus)

6. Social concept of UECBR (2014), UECBR, Moscow, p. 15 (rus).

(c) Черенков Михайло

Надійшла до редакції 09.02.2015

\section{ГУРЖИ ВОЛОДИМИР,}

аспірант кафедри філософії Донецького національного університету, м. Вінниця, експерт Украӥнського інституту стратегій глобального розвитку $і$ адаптаціi

\section{НАСЛІДКИ РЕАЛІЗАЦІЇ ДОКТРИНИ "РУССКІЙ МІР" В УКРАЇНІ}

У статті проаналізовано зміни у соціально-політичній, релігійній ситуації в Україні останніх років, а також наслідки реалізації доктрини "Русскій мір" на їі східних територіях. Наводяться історичні й теоретичні витоки, а також головні ідейні засади доктрини "Русскій мір", описані методи експорту культурних і релігійних цінностей як важелів у проведенні зовнішньої політики. Виявлено підґрунтя впливу доктрини "Русскій мір" в Україні.

Ключові слова: "Русскій мір"; православ'я; геополітична доктрина; конфрлікт в Україні.

Постановка проблеми та стан її вивчення. Ще не так давно Україна асоціювалась з пострадянською державою, в першу чергу відомою у світі завдяки успіхам у спорті Андрія Шевченка і братів Кличків, а також порушенням свободи слова, слабкою економікою і корумпованою владою. Все змінилося наприкінці 2013 року, коли протести у Києві і деяких західних областях призвели до втечі влади з країни, що стало справжнім інформаційним бумом у світі, який з часом тільки посилювався. Подальші події у Криму, а згодом у Донецькій та Луганській областях спричинили справжню інформаційну війну, українська тема не сходить зі шпальт газет і екранів телевізорів, у соціальних медіа вона тримає першість вже більше року. Саміти провідних по- літиків світу присвячуються кризі в Україні і шляхам їі подолання. I все частіше можна почути думку, що у Донбасі зараз вирішується доля світу, а можливість Третьої світової війни, як ніколи, близька. Ще донедавна потужний промисловий центр країни став ареною боротьби двох "життєвих світів", ідеологічних систем, способів світосприйняття - західноєвропейської моделі розвитку і "Русского міра". Можливо, саме зараз проходить становлення української державності і вибір моделі державного устрою, який буде адекватно відповідати українській дійсності, проте поки що невідомо, що переважить на терезах: людське життя і кількість загиблих, зруйновані міста, чи отримання "нової держави", яка ризикує втратити незалежність? 
Науковий аналіз історико-політичних та соціокультурних наслідків впровадження концепції "Русского міра" в сучасній Україні виконаний в роботі українського історика Я. Потапенка (2013), який попереджав про надзвичайно велику загрозу для майбутнього української держави та перспектив консолідації і ціннісної самоідентифікації нації [1]. У більш ранніх публікаціях Я. Грицака, Ю. Макарова, І. Лосєва, М. Рябчука, О. Литвиненка, Я. Музиченка та інших дослідників також наголошується на "кремлівському підпорядкуванні" цієї концепції і на тому, що вибір на користь "Русского міра" засвідчить неспроможність нашої країни ментально, ідеологічно й політично відірватися від цілком іншої цивілізації, у якій церковно-релігійна ідентичність переважає національно-державну [2-6].

Наразі маємо загострення протистояння двох ідеологічних парадигм, що вилилося у збройний конфллікт, а отже й нові результати реалізації доктрини "Русского міра" на східних теренах України. Тож на часі - продовження аналізу процесів "русифікації-совєтизації" України як наслідку дії цієї доктрини.

Мета статті - на підставі аналізу змін соціально-політичної, релігійної ситуації в Україні останніх років, показати наслідки реалізації доктрини "Русскій мір" на їі східних територіях.

Виклад основного матеріалу. Росія не успадкувала від Радянського Союзу статус наддержави, який мав СРСР, проте будь-яким чином намагалася зберегти вплив на колишні радянські республіки, які стали на шлях самоідентифікації і незалежності. Це вилилось у ряд воєнних конфрліктів на початку 1990-х років: у Нагірному Карабасі, Придністров'ї, Південній Осетії, Абхазії і Чечні, проте ці конфрлікти не були достатньо ідеологічно опрацьовані, що призвело до втрати і без того невиразного міжнародного авторитету держави. 3 цього приводу досить чітко висловився колишній голова комітету Державної Думи РФ у зовнішніх справах К. Косачев: "Зачастую мы не можем толком объяснить сам смысл нашего присутствия на постсоветском пространстве, полагая это чем-то аксиоматичным. Запад делает это под фрлагом демократизации, а мы, получается, только во имя себя самих. Но лозунги демократии (даже с учетом явной геополитической подоплеки) адресованы самим народам, а наша активность слишком откровенно преследует российские интересы. Это патриотично, но неконкурентоспособно. Между тем нам следует предлагать что-то во имя самих этих стран, понятное и доступное: "рост, модернизация, независимость"; какие-то объединительные, а не пророссийские проекты" [14]. Починаючи з 2004 року російські ідеологи почали активно шукати тих, кого необхідно "захистити". Враховуючи компактне проживання етнічних росіян у колишніх радянських республіках, довго шукати не довелось. "Российская диаспора предлагает социальную и гуманитарную основу для осуществления интересов Российской Федерации на постсоветском пространстве ...", "... в качестве геополитической концепции, "Русский мир" полезен в странах Восточной Европы, которые Россия намерена держать в своей орбите и в которых она готова пойти на интервенцию, в случае, если те выберут иную внешнюю политику," відмічав колишній заступник голови департаменту співвітчизників за кордоном О. Чепурін [7]. Захист інтересів російськомовного, православного населення для цього прекрасно підходив. Так з'явилася необхідність переосмислення "Русского міра" у геополітичну доктрину і політтехнологію.
Дискусію про "Русскій мір", яка велась у Росії в 1990-х - на початку 2000-х років, можна звести до пошуків і спроб зберегти культурну ідентичність російського народу, ба навіть віднайти нову, взамін втраченої радянської. 3 цього приводу найчастіше згадують імена Петра Щедрицького, а також Юхима Островського. За даними "Русского журнала" обидва входять у список найоплачуваніших у світі політтехнологів і фахівців з управління політичними кризами. Встигли вони попрацювати і в Україні, починаючи з 1993 року, співпрацювали $з$ Л. Кучмою, В. Пінчуком, з 1998-го з В. Хорошковським, а також деякими комерційними банками, 3 "Командою Озимого Покоління" (до якої також входив В. Хорошковський) - з 2001 року; обидва фрахівця також входили до штабу Наталії Королевської 2012 року. Проект "Озимого покоління" можна назвати невдалим, проте перша п'ятірка списку зробила чудову політичну кар'єру. 3 огляду на все це досить цікава участь П. Щедровицького у проекті "Иное. Хрестоматия нового российского самосознания" 1995 року, в якому також брали участь: А. Кураєв, С. Чернишев, В. Каганский, С. Кургінян та багато інших. Це чотиритомне видання, придбати яке наразі можливо лише у "Російському інституті". Суть роботи можна звести до тези одного з авторів: "Иное - философский пароход, который возвращается на родину". В основу покладене осмислення тих принципових викликів, які отримала Росія після розпаду Радянського Союзу. Організатори проекту мали на меті організувати певний процес, об'єднати схожі, проте розрізнені ідеї й донести їх фрахівцям у різних галузях науки: "... Предположим, что некоторую страну поразил духовный голод. На ней не сеют трансцендентные зерна истины, блага и красоты, не жнут урожай, не молотят, не свозят его в элеваторы и разнообразные закрома, не мелют муку, не пекут хлеб и не распространяют его тем или иным способом через торговую сеть или систему полевых кухонь. Как известно, чем сильнее духовная дистрофия, тем беспощаднее огонь материальной вражды, который невозможно потушить материальными же средствами. В этой ситуации задачей-максимум является возрождение культуры смыслоделия, возделывания духовной почвы. Но первым шагом должно стать осознание самого факта трансцендентного голода, понимание, что функция духовного питания общества, функция целеполагания разрушена, нуждается в скорейшем восстановлении и институционализации...", - пише у передмові С. Чернишев [8]. Роботу Щедровицького у даній збірці, а також подальшу співпрацю автора роботи з Островським слід вважати основою ідей "Русского міра", у тому його вигляді, з яким ми маємо справу наразі. Так, саме російська мова стає приводом розширення впливу "Русского міра" за кордон; "Русскій мір" - це і $є$ спільноти людей, які розмовляють російською, не важливо, де фрізично вони знаходяться, якщо духовно вони у Росії. Фактично Росія була винесена за межі фрізичного й перетворилася, швидше, на культурне явище, тому там, де розмовляють російською мовою, там і $є$ Росія. На думку П. Щедровицького, це відкривало доступ Росії насамперед до економічних складових країн, у яких приживає російська діаспора. Проте на той час подібні ідеї вважалися суто теоретичними і навіть утопічними.

Все змінилося, починаючи з середини 2000-х років. Поступово "Русскій мір" перейшов з інтелектуальних кіл до владних кабінетів Кремля і Російської православної церкви, ставши одним з основних векторів у зовнішній політиці Росії. У першу чергу це пов'язано з високою 
привабливістю і великим мобілізаційним потенціалом даної концепції, адже вона не несе у собі політичної або соціально-економічної ангажованості - лише культурні та етичні смисли, не обмежує Росію лише її кордонами, а навпаки - відкриває можливості зовнішньополітичного впливу на країни, де існує російськомовна діаспора, стає не важливо, хто ти етнічно, які в тебе політичні погляди і соціальний стан. Такий підхід дозволив зробити, здавалося, неможливе: наприклад, з'явилися православні комуністи з гаслами на кшталт: "Задача номер один для Русского мира - православие и советский проект должны объединить усилия". Наприкінці 2006 року президент РФ В. Путін на зустрічі 3 творчою інтелігенцією сказав: "Русский мир может и должен объединить всех, кому дорого Русское слово и Русская культура, где бы они не жили, в России или за её пределами. Почаще употребляйте это словосочетание - "Русский мир" [9]. Трохи пізніше, 2007 року, указом президента РФ був створений фонд "Русскій мір", який мав на меті популяризацію в Росії і світі російської мови і культури. "Сейчас под эгидой фонда работает 100 Русских центров в 45 странах и 145 Кабинетов Русского мира в 56 странах - от Аргентины до Армении". "Мир не состоит из Прибалтики, Украины и некоторых восточно-европейских стран, где происходят какие-то нападения на Фонд "Русский мир". Поэтому мы просто с высоко поднятой головой продолжаем свою миссию и будем ее продолжать независимо от того, нравится она кому-то или нет". "За последний год изменился Русский мир, его изменила Украина. Семь лет назад мы говорили о Русском мире как о культурном феномене, мы говорили о мире Русского языка и культуры. Сейчас все чаще Русский мир политизируется и становится категорией не столько культурной, сколько политической" - розповів виконавчий директор фонду Володимир Кочін [10]. А вже у листопаді 2010-го Патріарх Московський і всея Русі Кирило заявив: "Ядро Русского мира - Украина, Беларусь, Россия. Основа Русского мира Русский язык, Русская культура, православие. Киев колыбель Русской цивилизации" [11].

Проте орієнтація на діаспору позначилась всередині самої Росії. Виходячи з опитувань "Всероссийского центра изучения общественного мнения" у листопаді 2014 року, 71\% росіян ніколи не чули поняття "Русскій мір"; з тих, хто розуміє це поняття, 52\% не відносять до нього центральну і західну Україну, проте відносять Донбас (72\%) [12]. Коментуючи це опитування, протоієрей В. Чаплін зауважив: "Я рад тому, что более четверти наших сограждан уже знают о понятии "Русский мир". Оно ведь новое. Оно появилось всего несколько лет назад и сейчас идет довольно широкая заинтересованная дискуссия о том, кого к "Русскому миру" можно относить и кто себя сам к нему относит". "Мы побеждали многие нашествия с Востока и Запада, победим и тех, кто пытается навязать нам жизнь по чужим правилам. Победим и Америку - не обязательно на поле боя, но на поле идей и смыслов. Мы говорим вещи, более очевидные для людей всего мира, мы задаем такие вопросы, на которые не могут ответить люди, которые строят мировую власть. Ибо за нами - правда" [13].

2010 року цим же центром було проведено ряд опитувань з метою виявити ступінь релігійності росіян. Дослідження показало, що лише $2 \%$ росіян дотримується Великого посту, а $71 \%$ не вважає за потрібне це робити, так само лише 2\% сповідуються 1 раз на місяць, або частіше, як правило, це ті самі люди, що дотримуються посту. Також було виявлено, що $33 \%$ росіян не знають жодної заповіді, а близько 15\% вважають заповідями інші фрази, які до них не відносяться. За тими самими ж даними до Руської православної церкви себе відносять лише $41 \%$ росіян, ще $25 \%$ просто "вірують у Бога", 21\% - намагаються вірити "більше ніж зараз" [15].

Подібна статистика наводить нас на роздуми щодо ідейної основи "Русского міра". Одразу пригадуються гасла "Москва - третій Рим" та "Свята Русь". Як відмітив 2010 року на круглому столі "Український світ и Русский мир. Антропоаспект" С. Градіровський: "Дискуссия стихла, потому что в России стала доминировать грубая сила. А еще позже словосочетание "Русский мир" подхватил Никонов, создал фонд, начал делать проекты, все это с другими деньгами и другим политическим весом. За тему взялся и новый патриарх. Но, надо признать, РМ отныне выглядит как геополитический, и еще больше как бизнесово-диаспоральный проект" [16].

Коли "Русскій мір" узяла на "озброєння" російська влада, для популяризації і більшої доступності, для створення певної зацікавленості у населення, його максимально ідеологічно спростили. Тому до ідейних основ радше необхідно відносити твердження "Оплот православ'я", "Діди воювали" i, як похідну від попередніх: "Крим - наш". Розглянемо їх більш детально.

Твердження перше: РПЦ - основа Вселенського православ'я і єдина церква, яка зберегла автентичну віру. Ця ідея повертає нас до Фераро-Флорентійського собору середини XV століття, на якому християн східного обряду представляли патріархи Константинополя i Києва. Після прийняття Флорентійської унії Київський патріарх отримав опір у Москві, де знаходилась його резиденція і виїхав до Риму, а від Київської церкви відділилась Московська у неканонічний шлях. Фактично собор, який був покликаний зменшити протиріччя, поглибив розкол між західною і східною гілками християнства. Після падіння Константинополя унія втратила своє політичне значення, а релігійного, здається, ніколи й не мала. Отже Вселенське православ'я базується на ідеї "Пентархії", тобто 5 найдавніших і ключових церков для християн східного обряду. До їх складу входять: Константинопольська, Олександрійська, Антіохійська, Єрусалимська і Кіпрська канонічні помісні церкви. Також досить цікавою $€$ фрраза з тумосу Вселенського патріарха Григорія VII від 13 листопада 1924 року: "... перше відділення від Нашого Престолу Київської Митрополії й залежних від неї Православних Митрополій Литви та Польщі, а рівно ж долучення їх до Святої Московської Церкви наступило не за приписами канонічних правил, а також не дотримано всього того, що було установлено відносно повної церковної автономії Київського митрополита, який носив титул Єкзарха Вселенського Престолу" [17].

Твердження друге: Росія самостійно перемогла у Великій Вітчизняній війні, звільнивши Європу від фашизму. Витоки цієї ідейної основи походять багато в чому з радянської пропаганди, проте нового виміру їй надав виступ В. Путіна у грудні 2010 року: "Теперь по поводу наших отношений с Украиной... Я позволю с вами не согласиться, когда вы сейчас сказали, что если бы мы были разделены, мы не победили бы в войне. Мы все равно бы победили, потому что мы страна победителей". "... война выиграна, не хочу никого обижать, за счет индустриальных ресурсов РФ. Это исторический фракт, это все в документах" [18]. Почати необхідно 3 того, що Друга світова війна - це глобальний процес, у якому брали участь 63 держави, на трьох континентах і у водах чотирьох океанів. Це найбільший збройний 
конфлікт за всю історію людства, загальна кількість загиблих приблизно 65 мільйонів людей. СРСР, дійсно, одна з країн-переможниць, проте це союз, до складу якого входило 15 республік і Росія лише одна з них. Наприклад, втрати Української РСР складають приблизно $45 \%$ від загальних втрат СРСР у війні. Назва "Велика Вітчизняна війна" існувала лише у Радянському Союзі, наразі лише у Росії. Інший світ не називав окремими війнами протистояння декількох держав у Другій світовій війні, подібна назва не згадується у західних джерелах, а розглядається лише як період участі СРСР у конфллікті. Радянська пропаганда намагалась звести усю війну до протистояння СРСР і Німеччини, і в певному сенсі їй це вдалося, проте чи відповідає це дійсності? Особлива роль у 9-го травня, "Дня перемоги", яке для інших країн-учасниць - день жалоби за загиблими, день скорботи, і нагадування про трагедію, яка ледь не призвела до загибелі людства. У СРСР, а нині в Росії і деяких колишніх республіках, цей день символізує одне з найбільших свят, яке підкреслює воєнну міць держави.

Поєднання двох попередніх ідейних основ явило третю: "Крим - наш". Першою спадає на думку розмова В. Путіна з Дж. Бушем 2008 року на саміті НАТО в Бухаресті. "Ты же понимаешь, Джордж, что Украина это даже не государство! Что такое Украина? Часть ее территорий - это Восточная Европа, а часть, и значительная, подарена нами!" - заявив президент РФ [19]. Це був, мабуть, перший відкритий і агресивний виступ В. Путіна, в якому державність України ставилась під сумнів.

"Для России Крым, древняя Корсунь, Херсонес, Севастополь имеют огромное цивилизационное и сакральное значение так же, как Храмовая гора в Иерусалиме для тех, кто исповедует ислам и иудаизм. И именно так мы будем к этому относиться отныне и навсегда", "Ведь именно здесь, в Крыму, в древнем Херсонесе, или, как его называли Русские летописцы - Корсунь, принял крещение князь Владимир, а затем крестил всю Русь", - сказав президент РФ В. Путін у зверненні до Федеральних зборів у грудні 2014 року [20]. Можна досить довго говорити про те, що Путін у виступі суперечить сам собі: Володимир був Київським князем, Москви ще не існувало, росіян - тим більше, до хрещення всієї Русі було ще далеко, а перша друкована Біблія взагалі з'явилась на цій території лише на наприкінці XVI століття і т.і. Насправді, у цій ситуації потрібно бути із собою максимально відвертим: уже не важливо, чи були вибори в Криму легітимними, чи була там російська армія, і чи справді Крим так хотів повернутися до Росії? Важливо те, що наразі це територія іншої держави, яка для України, мабуть, втрачена. Кримом володіє той, чий флот там базується. Українського фрлоту там немає. Наприкінці лютого 2014 року нове керівництво України не змогло втримати частину своєї території і, здається, нічого для цього не зробило, апеляції до принципу непорушності державних кордонів і заклики до країн Західної Європи, а також США, не можна вважати адекватними заходами. Це виглядало так, ніби вам відтинають ногу, а ви розповідаєте про принципи гуманізму і людське життя як найвищу цінність. Головне питання "Крим - це Україна, чи Росія?" можливо, залишається, хоча у автохтонного населення - кримських татар, мабуть, $є$ своя думка з цього приводу.

Постійні апеляції владної верхівки російської держави до православ'я, його ключової ролі у державотворенні й російській самосвідомості підштовхують нас до осмислення діяльності Російської православної церк- ви і Української православної церкви Московського патріархату на території України. Насамперед слід звернутися до статистичних даних для більш чіткого розуміння масштабу і можливостей цієї організації. За даними "Центру Разумкова" [21] станом на 2014 рік 76\% населення України відносять себе до "віруючих", незалежно від того, відвідують вони церкву, чи ні. 70,2\% відносять себе до православних, з них до Московського патріархату - 24,8\%, Київського патріархату - 31,9\%, "просто православний" - 39,8\%. Наприклад, у Донецьку за підтримки УПЦ МП існує телеканал КРТ, а також видається 3 православних журнали і 2 газети. I це при тому, що на сході країни до віруючих себе відносять $62 \%$ людей, а наприклад, на заході - 93\%. Представники Київського патріархату подібну діяльність не ведуть, а частка греко-католиків надзвичайно мала. Подібна діяльність не обмежується газетами і телевізійним простором, якщо займатися аналізом програмних документів "народних республік", наприклад конституції ДНР, можна побачити наступне: "МЫ, ВЕРХОВНЫЙ СОВЕТ ДОНЕЦКОЙ НАРОДНОЙ РЕСПУБЛИКИ, ОЩУщая себя неотъемлемой частью Русского Мира как Русской цивилизации, общности Русских и других народов, мысля нераздельность судьбы всего Русского Мира и желая по-прежнему оставаться ее причастниками, оставаясь приверженными идеалам и ценностям Русского Мира и чтя память предков, проливших кровь за эти идеалы и ценности и передавших нам любовь и уважение к общему Отечеству, исповедуя Православную веру (Веру Христианскую Православную Католическую Восточного Исповедания) Русской Православной Церкви (Московский Патриархат) и признавая ее основой основ Русского Мира, а также сознавая историческую ответственность и выражая волю многонационального народа Донецкой Народной Республики, выраженную в решении референдума от 11 мая 2014 года, следуя общепризнанным принципам равноправия и самоопределения народов и провозглашая незыблемость демократических принципов формирования и осуществления власти, подтверждаем государственный суверенитет Донецкой Народной Республики на всей её территории и создание суверенного независимого государства, ориентированного на восстановление единого культурно-цивилизационного пространства Русского Мира, на основе его традиционных религиозных, социальных, культурных и моральных ценностей с перспективой вхождения в состав Большой России как ореола территорий Русского Мира, и принимаем настоящую Конституцию Донецкой Народной Республики" [22]. Колишній радник міністра оборони ДНР 3 інформаційної політики, у серпні 2014 року у своєму інтерв'ю заявив: "С украинской стороны православных нет вообще, потому что ни один воцерковленный православный человек не пойдет воевать против Новороссии, потому что знает, что единство Святой Руси угодно Богу. Все святые, которые говорили на эту тему, единогласны в том, что Святая Русь должна быть едина. А вот укро-фашисты как раз и являются сепаратистами и хотят отколоть Новороссию от Святой Руси и присоединить ее к загнивающему воинствующему Западу. Поэтому церковных людей с украинской стороны нет вообще. В карательных батальонах в основном униаты, раскольники, неоязычники и сектанты. Среди армейских солдат много людей, формально крещеных в Украинской Православной Церкви Московского Патриархата, но не знающих даже азов православного вероучения, Символа веры" [23]. До складу так званих "збройних сил" ДНР і ЛНР входять підрозділи, які позиціону- 
ють себе, як релігійні. Наприклад, "Русская православная армия", православний батальйон "Восход", Легіон Святого Іштвана, батальйон Пресвятої Богородиці Августовської "Август". Такими діями у загальний малюнок конфрлікту було внесено релігійні мотиви з подальшим намаганням вивести їх на передній план: мовляв, істинно православні воїни захищають віру своїх предків, що закріплена в конституції ДНР. Звісно, офріційна позиція РПЦ і УПЦ МП є досить чіткою, наприклад, протоієрей Г. Коваленко, голова Синодального інформаційно-просвітницького відділу УПЦ МП у червні 2014 року заявив: "Русская Православная Церковь не благословляла "Русскую православную армию" воевать за "Русский мир" [24]. Подібна реакція церковних ієрархів не дивна, РПЦ не може дозволити собі офріційну підтримку "республік" і втрату іншої частини України, проте офріційно в Україні немає ані війни, ані російських солдатів.

\section{Висновки}

Виходячи з усього вище викладеного, постають питання: чи дійсно на Донбасі були і $€$ такі сильні позиції "Русского міра"? Чи, можливо, має місце різне бачення української державності, розігране "зовнішніми силами"? I як так сталося, що на адміністративній території, на якій за часи незалежності не відбувалося практично жодного протесту або страйку і населення якої $\epsilon$ найменш релігійним у країні, з'явилися фактично "релігійні армії", які відстоюють "свій життєвий уклад і віру предків"? Питання досить складні і навряд чи мають однозначні відповіді, прийнятні для всіх учасників конфлікту.

Насправді Росія ніколи не бачила Україну незалежною державою. Наприклад у збірнику Інституту Європи PAН "Українська криза: експертна оцінка" [25], який вийшов наприкінці 2014 року, можна простежити наступні інтенції: розпад України - природний процес, продовження розпаду СРСР; Україна штучна країна, насильницьке зібрання різних народів з різною ідентичністю. Також наголошують на тому, що російська наука ніколи не займалася комплексним вивченням України, вважаючи ії частиною себе. Отож нічого дивного не має у тому, що "добровольці" з Росії захищають "свою" землю, православну віру і традиції. Таке поєднання елементів православного християнства, ідеології, геополітичних концепцій з нестійкою державною ситуацією, невдалими кроками влади у керуванні країною, тяжким економічним становищем у сумі дали східноукраїнський конфрлікт. Ця ситуація не виникла одномоментно разом із закінченням "Євромайдану", а стала наслідком тривалої незацікавленості держави у вирішенні насамперед ідеологічних питань, а також у веденні адекватної інформаційної політики, популяризації української мови і культури, прищепленні населенню ідеї українськості, що не протирічить локальним культурним особливостям певної території, а навпаки, доповнює їх. Чи було у неї вирішення? Очевидно, існувала певна послідовність з вдалих політичних і економічних, а також силових кроків, які могли б призвести до покращення ситуації. Чи були сторони конфлікту зацікавлені у вирішенні? Мабуть, у кожного з нас $€$ своя відповідь.

\section{ЛIТЕРАТУРА}

1. Потапенко Я. Історико-політичні та соціокультурні наслідки впровадження псевдорелігійної концепції "Русского міра" в сучасній Україні / Я. Потапенко // Наукові записки з української історії . - 2013. - Вип. 33. - С. 291-297. [Електронний peсурс]. - Режим доступу: http://nbuv.gov.ua/j-pdf/Nzzui 2013_33_47.pdf

2. Грицак Ярослав. Куди рухається цей світ? / [Електронний ресурс]. - Режим доступу: culture.unian.net/ukr/detail/ 190240.

3. Лосєв І. Безальтернативність цивілізаційного розмежування / І.Лосєв // Український тиждень. - № 19 (287). 2013. - C.22-25.

4. Макаров Ю. Свято з чужої вулиці / Ю.Макаров // Український тиждень. - № 19 (287). - 2013. - С.21.

5. Музиченко Я. Хрещення Києва - по-московськи? / Я.Музиченко // Україна молода. - 17-18 травня 2013. - С.5

6. Рябчук М. Патріарші візити як дзеркало креолізації / М. Рябчук // Постколоніальний синдром. - К.: "К.І.С.", 2011. C.223-227.

7. Путин, симуляция консерватизма, или Русская агентура на Западе [Електронний ресурс]. - Режим доступу: http:/ /gilgames-feanor.livejournal.com/75254.html

8. "Хрестоматия нового российского самосознания" [Електронний ресурс]. - Режим доступу: http://old.russ.ru/antolog/ inoe/

9. МЫ РУССКИЙ МИР ПОСТРОИМ! [Електронний ресурс]. - Режим доступу: http://old.Igz.ru/archives/html_arch/lg492006/ Polosy/1_1.htm

10. ПРИТЯЖЕНИЕ РУССКОГО МИРА [ЕлектроннИЙ ресурс]. - Режим доступу: http://sr.fondedin.ru/new/fullnews.php? subaction $=$ showfull\&id $=1409560529$ \&archive $=1409042400 \&$ start from $=\&$ ucat $=14 \&$

11.Выступление Святейшего Патриарха Кирилла на торжественном открытии III Ассамблеи Русского мира [Електронний ресурс]. - Режим доступу: http://www.patriarchia.ru/ $\mathrm{db} /$ text/928446.html

12. "РУССКИЙ МИР" И КАК ЕГО ПОНИМАТЬ?" [Електронний ресурс]. - Режим доступу: http://wciom.ru/index.php?id $=459$ \&uid $=115074$

13. Русский мир немыслим без православия [Електронний ресурс]. - Режим доступу: http://ria.ru/religion/20141208/ 1037121524.html

14. Konstantin Kosachev, Нефтегазовая дипломатия как угроза маргинализации, Nezavisimaya Gazeta (Dec. 28, 2004), http://www.ng.ru/world/2004-12-28/5_uspeh.html

15. РЕЛИГИОЗНОСТЬ РОССИЯН И ЕВРОПЕЙЦЕВ [ЕЛЕКТронний ресурс]. - Режим доступу: http://wciom.ru/fileadmin/ Monitoring/96 1/2010 2(96) 10 Kofanjva.pdf

16. Руссскій Міръ [Електронний ресурс]. - Режим доступу: http://blogs.pravda.com.ua/authors/okara/4c48444962e33/

17. Короткий опис проголошення автокефалії основних Помісних Церков [Електронний ресурс]. - Режим доступу: http://www.cerkva.info/icd/203-declaracia-5-2.html

18. Путин: Мы бы победили в Великой Отечественной войне и без Украины [Електронний ресурс]. - Режим доступу: http://censor.net.ua/video_news/146646/putin_my_by_pobedili v velikoyi otechestvennoyi voyine i bez ukrainy dobavleno video

19. Путин: ты же понимаешь, Джордж, что Украина - это даже не государство! [Електронний ресурс]. - Режим доступy: http://www.unian.net/politics/108325-putin-tyi-je-ponimaeshdjordj-chto-ukraina-eto-daje-ne-gosudarstvo.html

20. Послание Федеральному Собранию [Електронний ресурс]. - Режим доступу: http://ruinformer.com/page/vladimir-putindlja-rossii-krym-drevnjaja-korsun-hersones-sevastopol-imejutogromnoe-civilizacionnoe-i-sakralnoe-znachenie

21. УКРАЇНА-2014: СУСПІЛЬНО-ПОЛІТИЧНИЙ КОНФЛІКТ । ЦЕРКВА [Електронний ресурс]. - Режим доступу: http:// www.razumkov.org.ua/upload/1403784760 file.pdf

22. КОНСТИТУЦИЯ ДОНЕЦКОЙ НАРОДНОЙ РЕСПУБЛИКИ [Електронний ресурс]. - Режим доступу: http:// dnrespublika.info/\%D0\%BE-\%D1\%80\%D0\%B5\%D1\%81\% D0\%BF\%D1\%83\%D0\%B1\%D0\%BB\%D0\%B8\%D0\%BA\%D0\% B5/konstituciya-doneckoj-narodnoj-respubliki/

23. Игорь Друзь: "Православный человек никогда не будет воевать против Новороссии" [Електронний ресурс]. 
Режим доступу: http://www.religion.in.ua/zmi/foreign_zmi/27055igor-druz-pravoslavnyj-chelovek-nikogda-ne-budet-voevat-protivnovorossii.html

24. Пресс-секретарь УПЦ МП: Церковь осуждает "политическое православие", когда для достижения земных целей используют религиозную риторику [Електронний ресурс]. - Режим доступу: http://gordonua.com/news/separatism/Presssekretar-UPC-MP-Cerkov-osuzhdaet-politicheskoe-pravoslaviekogda-dlya-dostizheniya-zemnyh-celey-ispolzuyut-religioznuyuritoriku-27530.html

25. Украинский кризис: экспертная оценка [Електронний ресурс]. - Режим доступу: http://www.sov-europe.ru/2014/3/ Ukk.pdf

Гуржи Владимир, аспирант кафедры философии

Донецккого национального университета, г. Винницฺа
26. Україна та проект "Русского мира" [Електронний ресурс]. - Режим доступу: http://www.niss.gov.ua/public/File/ 2014_nauk_an_rozrobku/Rus_mir.pdf

27. Русский язык и Русский мир как фракторы социокультурного диалога на постсоветском пространстве [Електронний ресурс]. - Режим доступу: http://www.lihachev.ru/pic/site/ files/lihcht/2010_Sbornik/Tom_1_2010/000_Plenarnoe_zasedanie/ 056_E.I.Pivovar.pdf

28. Навернення малоросів: доктрина "Русскаго міра" як стимул до побудови нової універсальної української ідентичності [Електронний ресурс]. - Режим доступу: http:// dspace.pnpu.edu.ua/bitstream/123456789/1378/1/Okara.pdf

\section{ПОСЛЕДСТВИЯ РЕАЛИЗАЦИИ ДОКТРИНЫ "РУССКИЙ МИР" В УКРАИНЕ}

В статье проанализированы изменения в социально-политической, религиозной ситуации в Украине последних лет, а также последствия реализации доктрины "Русский мир" на ее восточных территориях. Приводятся исторические и теоретические истоки, а также главные идейные основы доктрины "Русский мир", описаны методы экспорта культурных и религиозных ценностей как рычагов в проведении внешней политики. Выявлено основы влияния доктрины "Русский мир" в Украине.

Ключевые слова: "Русский мир"; православие; геополитическая доктрина; конфрликт в Украине.

Gurzhi Volodymyr,

Postgraduate student of philosophy, Donetsk National University, Vinnytsia

\section{CONSEQUENCESTO IM PLEM ENT THE DOCTRINE "RUSSKY M IR" IN UKRAINE}

The article analyzes the changes in the socio - political, religious situation and the consequences of attempts to implement the doctrine of "Russky Mir" in Ukraine. We present theoretical and historical origins and main ideological foundations of the doctrine "Russian Mir", describes methods for exports of cultural and religious values as leverage in conducting foreign policy. Found ground impact doctrine "Russian Mir" in Ukraine.

Keywords: "Russky Mir"; Orthodoxy; geopolitical doctrine; conflict in Ukraine.

\section{REFERENCES}

1. Potapenko Ya. (2013), Naukovi zapysky z ukrayinskoyi istoriyi [Scientific Proceedings of Ukrainian history], Vol. 33, p. 291-297, available at: http://nbuv.gov.ua/j-pdf/Nzzui 2013 33 47.pdf

2. Hrytsak Yaroslav. Where is the world? available at: culture.unian.net/ukr/detail/190240.

3. Losiev I. (2013), Ukrayinskyy tyzhden, №19 (287), p. 22-25 (ukr).

4. Makarov Yu. (2013), Ukrayinskyy tyzhden, №19 (287), p. 21 (ukr).

5. Muzychenko Ya. (2013), Ukrayina moloda, 17-18 travnya, p.5 (ukr).

6. Riabchuk M. (2011), Patriarch visits as a mirror kreolizatsiyi in: Postcolonial syndrome, "K.I.S." Kyiv, p. $223-227$ (ukr).

7. Livejournal.com, available at: http://gilgames-feanor.livejournal.com/75254.html

8. Otherwise. Readings of the new Russian identity, available at: http://old.russ.ru/antolog/inoe/

9. Literary gazette, available at: http://old.lgz.ru/archives/html_arch/lg492006/Polosy/1_1.htm

10. Strategy of Russia, available at: http://sr.fondedin.ru/new/fullnews.php?subaction=showfull\&id $=1409560529 \&$ archive $=$ 1409042400\&start from $=\&$ ucat $=14 \&$

11. Official site of the Moscow Patriarchate, available at: http://www.patriarchia.ru/db/text/928446.html

12. Wciom, available at: http://wciom.ru/index.php?id=459\&uid $=115074$

13. Ria, (2015), available at: http://ria.ru/religion/20141208/1037121524.html

14. Nezavisimaya Gazeta (Dec. 28, 2004), available at: http://www.ng.ru/world/2004-12-28/5 uspeh.html

15. Wciom, available at: http://wciom.ru/fileadmin/Monitoring/96_1/2010_2(96)_10_Kofanjva.pdf

16. Pravda, blogs, (Febr. 21, 2015), available at: http://blogs.pravda.com.ua/authors/okara/4c48444962e33/

17. Official site of the Kiev Patriarchate, available at: http://www.cerkva.info/icd/203-declaracia-5-2.html

18. Censor, (Dec. 16, 2010), available at: http://censor.net.ua/video_news/146646/putin_my_by_pobedili_v_velikoyi_otechestvennoyi voyine_i_bez_ukrainy_dobavleno_video

19. UNIAN, (Apr. 7, 2008), available at: http://www.unian.net/politics/108325-putin-tyi-je-ponimaesh-djordj-chto-ukraina-eto-dajene-gosudarstvo.html http://www.unian.net/politics/108325-putin-tyi-je-ponimaesh-djordj-chto-ukraina-eto-daje-ne-gosudarstvo.html

20. INformer (Dec. 04, 2014), available at: http://ruinformer.com/page/vladimir-putin-dlja-rossii-krym-drevnjaja-korsun-hersonessevastopol-imejut-ogromnoe-civilizacionnoe-i-sakralnoe-znachenie

21. UKRAINE 2014: SOCIO-POLITICAL CONFLICT AND THE CHURCH, available at: http://www.razumkov.org.ua/upload/ 1403784760 file.pdf

22. DNR information portal, available at: http://dnrespublika.info/\%D0\%BE-\%D1\%80\%D0\%B5\%D1\%81\%D0\%BF\%D1\%83\%D0\%B1\% D0\%BB\%D0\%B8\%D0\%BA\%D0\%B5/konstituciya-doneckoj-narodnoj-respubliki/ 
23. Druz I., Religion in Ukraine, available at: http://www.religion.in.ua/zmi/foreign_zmi/27055-igor-druz-pravoslavnyj-chelovek-nikogdane-budet-voevat-protiv-novorossii.html

24. Gordon, available at: http://gordonua.com/news/separatism/Press-sekretar-UPC-MP-Cerkov-osuzhdaet-politicheskoepravoslavie-kogda-dlya-dostizheniya-zemnyh-celey-ispolzuyut-religioznuyu-ritoriku-27530.html

25. Fedorov V.P., UKRAINIAN CRISIS: EXPERT ASSESSMENT, available at: http://www.sov-europe.ru/2014/3/Ukk.pdf

26. ANALYTICAL REPORT, (2014), UKRAINE AND PROJECT "Russian World", available at: http://www.niss.gov.ua/public/File/ 2014_nauk_an_rozrobku/Rus_mir.pdf

27. Plenary Session "Dialogue of Cultures and Partnership of Civilizations: The Making of Global Culture", available at: http:// www.lihachev.ru/pic/site/files/lihcht/2010_Sbornik/Tom_1_2010/000_Plenarnoe_zasedanie/056_E.I.Pivovar.pdf

28. Publicistica, available at: http://dspace.pnpu.edu.ua/bitstream/123456789/1378/1/Okara.pdf

(C) Гуржи Володимир

Надійшла до редакції 04.02.2015

УДК 130.2

МОШОВСЬКИЙ ТАРАС,

кандидат філософських наук, магістр релігієзнавства,

експерт Українського інституту стратегій глобального розвитку $і$ адаптації

\section{УКРАЇНА: НАРОДЖЕННЯ ЧИ ПРОБУДЖЕННЯ СУБ'ЄКТА ІСТОРІї}

У статті зроблено спробу трактувати сучасний східноукраӥнський конфлікт не як протистояння Заходу і Росії чи внутрішній громадянський конфлікт, а виходячи 3 самої України, зі специфіки, закономірностей розвитку української історії, її внутрішніх детермінант і місця в історії європейської (християнської) цивілізації, через спробу простежити від києворуських часів до київських Майданів XXI століття єдність історичної дії, єдину історичну суб'єктність української (руської) культури.

Ключові слова: суб'єкт історії; українська нація; католицька Русь; Русь; східноукраїнський конфолікт.

Постановка проблеми і стан їївивчення. Фабіо Беллафратті у своєму свіжому дописі "Новий Орієнталізм. Колоніальні впливи в західних опініях про Україну" [1]. закидає західним інтелектуалам цілком колоніальне бачення України. Такий висновок автор робить, співставляючи тезу Едварда Саїда з хрестоматійної вже для будь-яких постколоніальних студій роботи "Орієнталізм", що побачила світ 1978 року, з останніми опусами західних експертів щодо українського конфлікту. Як азійським суспільствам, так і Україні Захід фактично відмовляє в праві бути суб'єктом історії, а лише її об'єктом. Не те щоб нас принципово позбавлено такого права, радше західна візія української історії й сьогодення змушує західних інтелектуалів мислити нас саме в категоріях об'єкта.

Чи так є насправді, чи така візія України відповідає дійсності, чи можливо це просто недостатне, або не до кінця коректне бачення України на Заході? Спробуємо з'ясувати, чи Україна справді тільки тепер стає суб'єктом історії, чи її суб'єктність має певну традицію, яку можемо осягнути в longue durée української історії.

Виклад основного матеріалу. Насамперед визначимось $з$ поняттями. Не заглиблюючись глибоко в теорію, скажемо, що під суб'єктом історії ми розуміємо спільноту, що здатна самостійно впливати і впливає на хід власної, а як наслідок і не тільки своєї історії. Яскравим прикладом тут безперечно будуть нації-локомоти- ви (англійці, фрранцузи, німці, росіяни), тобто ті нації, що сталим чином $€$ в авангарді європейської історії і продукують тренди, за якими слідують інші. Об'єктами ж історії стають народи, над якими чиниться історія.

Що ж робить об'єкт історії її суб'єктом?

Передусім варто зауважити, що суб'єкт - це а́ктор, себто діючий феномен. А будь-якій дії передує цілепокладання, бо діяти - то означає діяти заради певної мети. Так от момент, коли певна спільнота набуває своєї мети, вона, по-перше, стає суб'єктом історії, бо починає рухатись до поставленої мети, розуміючи шлях до реалізації цієї мети, як власну місію, що й наповнює змістом існування спільноти. Повертаючись до національного буття, мусимо констатувати, що саме в цей момент нація і стає нацією. Саме усвідомлення власної мети, місії власного існування започатковує той шлях, який торуватиме собі нація, старт цього шляху і стає моментом народження нації, яка може народжуватись чи то з культурних спільностей (євреї, німці, поляки) чи то з політичних (американці, швейцарці, австрійці'1). Початок такого історичного шляху до визначеної мети і $є$ становленням суб'єкта історії, бо і $є$ початком дії - реалізації власної мети. Отже, саме буття суб'єктом історії і конституює націю.

\footnotetext{
1 Останні наразі $€$ прикладом того, як нація народжується 3 династичної держави.
} 